\title{
PENGARUH KOMPETENSI APARATUR DESA DAN PERAN SERTA BPD TERHADAP KUALITAS LAPORAN KEUANGAN DESA DI TELUK SEBONG DAN TELUK BINTAN
}

\section{THE EFFECT OF VILLAGE APPARATUS COMPETENCY AND ROLE AND BPD ON THE QUALITY OF VILLAGE FINANCIAL STATEMENTS IN SEBONG AND TELUK BINTAN BAYS}

\author{
Asri Eka Ratih', Nurhasah. S ${ }^{2}$ \\ ${ }^{1}$ Universitas Maritim Raja Ali Haji \\ ${ }^{2}$ Universitas Maritim Raja Ali Haji \\ asriekaratih@umrah.ac.id
}

\begin{abstract}
ABSTRAK
Penelitian ini bertujuan untuk mengetahui dan mengukur tingkat kompetensi aparatur dan peran serta BPD dalam mewujudkan laporan keuangan desa dalam pengelolaan dana desa agar lebih berkualitas dan sesuai dengan standar. Hasil dari penelitian ini diharapkan nantinya dapat dijadikan salah satu tolak ukur keberhasilan atau tidaknya aparatur desa dalam mengelola dana desa serta mempertanggungjawabkannya dengan kompetensi yang dimiliki aparatur desa dan peran serta BPD. Penelitian ini dilakukan di desa Teluk Sebong dan Teluk Bintan, yang berjumlah 13 desa, yang menjadi sampel atau sasaran dalam penelitian ini adalah aparatur desa yang terdiri dari kepala desa, sekertaris desa, bendahara desa dan ketua BPD. Hasil dari penelitian menjelaskan bahwa semakin tinggi kompetensi yang dimiliki oleh aparatur desa, maka akan semakin baik kualitas laporan keuangan yang disajikan. Begitupula peran serta BPD dalam pelaksanaan dan pengeloaan dana desa, maka akan semakin baik kualitas laporan keuangan desa yang disajikan.
\end{abstract}

Kata Kunci : Kompetensi, Peran Serta BPD, Kualitas Laporan Keuangan Desa

\begin{abstract}
This study aims to determine and measure the level of competence of the apparatus and the role of the BPD in realizing village financial reports in managing village funds to be more qualified and in accordance with standards. The results of this study are expected to later be used as a benchmark for the success or failure of village officials in managing village funds and to account for the competencies possessed by village officials and the role of BPDs. This research was conducted in Teluk Sebong and Teluk Bintan villages, which numbered 13 villages, which were the samples or targets in this study were village apparatus consisting of village heads, village secretaries, village treasurers and BPD chairpersons. The results of the study explain that the higher the competencies possessed by the village apparatus, the better the quality of the financial statements presented. Likewise the role of the BPD in the implementation and management of village funds, the better the quality of village financial reports presented.
\end{abstract}

Keywords : Competence, Participation of BPD, Quality of Village Financial Reports 


\section{PENDAHULUAN}

Sejak dikeluarkannya Undang-Undang Nomor 6 Tahun 2014 tentang Desa perhatian yang besar ditujukan kepada pedesaan, hal itu didasarkan pada kenyataan bahwa desa merupakan tempat berdiamnya sebagian besar rakyat Indonesia, kedudukan desa dan masyarakat desa merupakan dasar landasan kehidupan bangsa dan negara Indonesia. Keberhasilan penyelenggaran pemerintahan di dalam suatu masyarakat akan turut ditentukan oleh para pemimpin masyarakat dan didukung oleh peran serta masyarakat, maka demikian pula pada penyelenggaran pemerintahan di desa memerlukan kemampuan dari pemimpin dan didukung oleh masyarakat desa setempat. Undang-Undang tentang Pemerintahan Daerah mengakui adanya otonomi yang dimiliki oleh Desa dan kepada kepala desa dapat diberikan penugasan ataupun pendelegasian dari pemerintah atau pemerintah daerah untuk melaksanakan urusan pemerintahan tertentu.

Berdasarkan ketentuan tersebut dikaitkan dengan kedudukan, tugas dan kewenangan Kepala Desa maka Kepala Desa beserta pengurus desa harus memiliki kompetensi sehingga mampu mengatur dan mengurus kepentingan masyarakatnya dengan melakukan kerjasama dengan semua unsur terkait di desa seperti dengan BPD, dengan Lembaga Kemasyarakatan Desa (LPM, PKK, Karang Taruna, dan lainnya), dan juga dengan masyarakat desa itu sendiri. Keberhasilan atau kegagalan penyelenggaraan pemerintahan desa sangat ditentukan oleh kompetensi aparatur desa, baik kompetesi pengetahuan, kompetensi keterampilan, maupun kompetensi sikap. Sejauh ini dari pengamatan yang dilakukan menunjukan bahwa aparatur desa masih belum memiliki kompetensi yang dapat menunjang dalam menyelenggarakan urusan yang kurang memadai untuk menyelenggarakan urusan pemerintahan desa. Kemampuan aparatur desa dalam menjalankan roda pemerintahan desa masih rendah. Oleh karenanya, implementasi UU.No. 6 Tahun 2014 tentang Desa beserta peraturan pelaksananya memerlukan 'capacity building' aparatur desa dari semua aspeknya, baik menyangkut perencanaan pemerintahan desa, pengelolaan keuangan desa, penyusunan kebijakan desa, kepemimpinan desa dan manajemen pelayanan desa. Selain dari pada itu pemerintah desa juga diberi tugas dan hak untuk mengelola dana yang diberikan dengan tujuan untuk pengembangan desa berikut masyarakat desa. Dengan begitu Kepala desa dan aparatur desa memiliki hak dan kewajiban untuk mengelola dana dan mempertanggungjawabkan dana yang telah diberikan. Dana desa itu sendiri harus dikelola dengan baik secara transparan dan akuntabel, dengan kondisi desa yang bermacam-macam, dengan berbagai dana pendamping yang masih banyak permasalahan serta penguatan kelembagaan yang masih baru, maka itu menjadi suatu beban dan cenderung menjadi boomerang bagi aparatur desa itu sendiri dalam pengelolaan dan pelaporan dana desa tersebut.

Berdasarkan Permendagri Nomor 113 Tahun 2014 tentang Pengelolaan Keuangan Desa dan Permendagri Nomor 1 Tahun 2016 tentang Pengelolaan Aset Desa. Desa berkewajiban untuk menyampaikan laporan desa (LRA dan Neraca) untuk dievaluasi oleh Kabupaten/Kota. Laporan pertanggungjawaban pengelolaan dana desa untuk saat ini mengacu pada KSAP (Komite Standar Akuntansi Pemerintahan). Untuk dapat melaksanakan seluruh tugas berikut kewajibannya kepala desa dan aparatur desa hendaknya memiliki kompetensi dan pemahaman akuntansi yang dapat mendukung kinerjanya dalam mengelola dana desa serta mempertanggungjawabkannya secara transparan dan akuntabel.

BPD yang bertugas sebagai pendampingan dalam menjalankan pemerintahan desa yang juga berfungsi sebagai pengawas, juga memiliki peranan yang penting dalam pelasanaan pemerintahan dan juga pengelolaan pemerintahan serta pengelolaan dana desa. BPD (Badan 
Permusyawaratan Desa) adalah merupakan perwakilan dari masyarakat desa yang ikut serta dalam membahas dan menyepakati rancangan peraturan desa yang dibuat bersama masyarakat dan aparatur desa, serta mengawasi pelaksanaannya. Jadi sudah selayaknya jika anggota BPD juga memiliki peran serta dalam keberhasilan dan kegagalan aparatur desa dalam melaksanakan tugas mengelola pemerintahan desa.

Umumnya, anggota Badan Permusyawaratan Desa belum berpengalaman dalam memahami dan merumuskan agenda-agenda yang diaharapkan secara efektif menciptakan pembaruan di desa. Diantara anggota Badan Permusyawaratan Desa, cukup banyak yang belum memahami hak dan tanggungjawabnya sebagai kekuatan legislasi dan pengontrol. Wajar bila kemudian, dalam penyelenggaraan Pemerintahan Desa, Kepala Desa masih lebih dominan dari pada Badan Permusyawaratan Desa.

Berdasarkan pengamatan, permasalahan yang sering terjadi dilapangan semenjak diserahkannya dana desa yang diberikan kepada desa, tidak sedikit kepala desa dan aparatur desa yang tersandung masalah serta tidak dapat memanfaatkan dan cenderung ragu mengelola dana desa, dikarenakan rasa tidak percaya diri dan ketidak pahaman dan minimnya kompetensi yang dimiliki kepala desa tersebut untuk mengelola dana desa, hal ini masih ditemui di beberapa desa yang terdapat di Kaupaten Bintan. Masih banyak aparatur kurang memiliki kompetensi yang diperlukan untuk penyelenggaraan pemerintahan desa, dilihat dari kompetensi pengetahuan/intelekktual, kompetensi keterampilan, dan kompetensi sikap. Indikasi masalah tersebut menarik untuk dikaji melalui suatu penelitian ilmiah, sehingga dipilih judul penelitian "Pengaruh Kompetensi Aparatur Desa dan Peran Serta BPD Terhadap Kualitas Laporan Keuangan Desa".

Berdasarkan latar belakang dan penjelasan serta permasalahan yang telah diuraikan diatas, maka dapat uraikan rumusan masalah dalam penelitian ini adalah 1) Apakah Kompetensi Aparatur Desa berpengaruh terhadap Kualitas Laporan Keuangan Desa? 2) Apakah Peran Serta BPD berpengaruh terhadap Kualitas Laporan Keuangan Desa ? 3) Apakah Kompetensi Aparatur Desa dan Peran Serta BPD berpengaruh terhadap Kualitas Laporan Keuangan Desa?, sedangkan tujuan dari penelitian ini adalah 1) Untuk megetahui pengaruh kompetensi aparatur desa terhadap kualitas laporan keuangan desa, 2) Untuk mengetahui pengaruh peran serta BPD terhadap kualitas laporan keuangan desa, 3) Untuk mengetahui pengaruh kompetensi aparatur desa dan peran serta BPD terhadap kualitas laporan keuangan desa.

\section{LANDASAN TEORI}

\section{Struktur Organisasi Desa}

Pemerintah desa berdasarkan Undang-Undang Nomor 6 Tahun 2014 adalah kepala desa atau yang disebut dengan nama lain dibantu perangkat desa sebagai unsur penyelenggara pemerintahan desa. Perangkat desa yang terdiri atas sekretariat desa, pelaksana kewilayahan, dan pelaksana teknis bertugas membantu kepala desa dalam melaksanakan tugas dan kewenangannya. Berdasarkan Permendagri Nomor 113 Tahun 2014 menyebutkan tugas-tugas aparatur desa adalah sebagai berikut :

Kepala Desa bertugas menyelenggarakan pemerintahan desa, pembinaan kemasyarakatan desa, dan pemberdayaan masyarakat desa. Kewajiban kepala desa adalah : 1) Memegang teguh dan mengamalkan pancasila, melaksanakan undang-undang dasar Negara Republik Indonesia tahun 1945, serta mempertahankan dan memelihara keutuhan Negara Kesatuan Republik Indonesia, dan Bhineka Tunggal lka. 2) Meningkatkan kesejahteraan 
masyarakat desa, 3) Memelihara ketentraman dan ketertiban masyarakat desa, 4) Menaati dan menegakkan peraturan perundang-undangan, 5) Melaksanakan kehidupan demokrasi dan berkeadilan gender, 6) Melaksanakan prinsip tata Pemerintahan Desa yang Akuntabel, transparan, profesional, efektif dan efisien, bersih, serta bebas dari korupsi, kolusi dan nepotisme, 7) Menjalin kerjasama dan koordinasi dengan seluruh pemangku kepentingan desa, 8) Menyelenggarakan administrasi pemerintahan desa yang baik, 9) Mengelola keuangan dan asset desa, 10) Melaksanakan urusan pemerintahan yang menjadi kewenangan desa, 11) Menyelesaikan perselisihan masyarakat desa, 12) Mengembangkan perekonomian masyarakat desa, 13) Membina dan melestarikan nilai sosial budaya masyarakat desa, 14) Memberdayakan masyarakat dan lembaga kemasyarakatan di desa, 15) Mengembangkan potensi sumber daya alam dan melestarikan likungan hidup, 16) Memberikan informasi kepada masyarakat desa.

Sekretaris desa bertindak selaku koordinator pelaksanaan pengelolaan keuangan desa dan bertanggung jawab kepada kepala desa, dengan tugas 1) Menyusun dan melaksanakan kebijakan pengelolaan APB Desa, 2) Menyusun dan melaksanakan kebijakan dan pengelolaan barang desa, 3) Menyusun Raperdes APBDesa, perubahan APBDesa, dan pertanggungjawaban pelaksanaan APBDesa, 4) Menyusun rancangan keputusan kepala desa tentang pelaksanaan peraturan desa tentang APBDesa dan perubahan APBDesa.

Badan permusyawaratan desa (BPD) adalah lembaga yang melaksanakan fungsi pemerintahan yang anggotanya merupakan wakil dari penduduk desa berdasarkan keterwakilan wilayah dan ditetapkan secara demokratis. Fungsi BPD diantaranya : 1) Membahas dan menyepakati Rancangan Peraturan Desa bersama Kepala Desa. 2) Menampung dan menyalurkan aspirasi masyarakat desa dan 3) melakukan pengawasan kinerja kepala desa

Bendahara dijabat oleh staf pada urusan keuangan. Bendahara mempunyai tugas menerima, menyimpan, menyetorkan membayar, menatausahakan, mempertanggungjawabkan penerimaan pemdapatan desa dan pengeluaran pendapatan desa dalam rangka pelaksanaan APBDesa.

\section{Kualitas Laporan Keuangan Desa}

Pengelolaan keuangan desa harus berdasarkan asas-asas, diantaranya transparansi, akuntabel, partisipatif serta dilakukan dengan tertib dan disiplin anggaran. Maka, sudah selayaknya laporan keuangan desa disusun dengan berdasarkan dan menganut asas-asas tersebut diatas, agar laporan keuangan itu lebih berkualitas dan memenuhi kebutuhan informasi yang dibutuhkan.

Laporan keuangan desa menurut Permendagri Nomor 113 Tahun 2014 yang wajib dilaporkan oleh pemerintah desa meliputi : Anggaran; Buku Kas; Buku Pajak; Buku Bank; dan Laporan Realisasi Anggaran (LRA). Sedangkan pihak-pihak yang menggunakan informasi keuangan desa diantaranya : Masyarakat desa; Perangkat desa; Pemerintahan daerah; dan Pemerintahan pusat

Keuangan desa adalah semua hak dan kewajiban desa yang dapat dinilai dengan uang serta segala sesuatu berupa uang dan barang yang berhubungan dengan pelaksanaan hak dan kewajiban desa, dimana pengelolaan keuangan desa adalah keseluruhan kegiatan yang dimulai dari perencanaan, pelaksanaan, penatausahaan, pelaporan, dan pertanggungjawaban keuangan desa. 
Laporan keuangan desa merupakan bentuk dari pertanggungjawaban yang harus dipertanggungjawabakan oleh kepala desa kepada masyarakat desa. Dalam menyusun laporan keuangan desa, kepala desa dibantu oleh bendahara yang telah dipilih. Kepala desa berkewajiban meyampaikan laporan realisasi pelaksanaan APBDesa kepada Bupati/Walikota berupa laporan semester pertama dan laporan semester akhir, menyampaikan laporan penyelenggaraan pemerintahan desa (LPPD) setiap akhir tahun anggaran, menyampaikan laporan keterangan penyelenggaraan pemerintahan desa secara tertulis kepada BPD setiap akhir tahun anggaran.

\section{Peran Serta BPD}

Badan Permusyawaratan Desa (BPD) atau yang disebut dengan nama lain adalah suatu lembaga dalam wilayah pemerintahan desa yang melaksanakan fungsi pemerintahan yang anggotanya merupakan wakil dari atau bagian dari masyarakat Desa yang ditunjuk atau dipilih berdasarkan keterwakilan wilayah dan ditetapkan secara demokratis. Badan Permusyawaratan Desa (BPD) juga merupakan lembaga yang berfungsi sebagai legislasi dan pengawasan terhadap pelaksanaan Peraturan Desa, Anggaran Pendapatan dan Belanja Desa serta Keputusan Kepala Desa, serta ikut berpatisipasi dalam merumuskan dan membuat peraturan desa bersama-sama dengan Kepala Desa. Disamping itu Badan Permusyawaratan Desa (BPD) juga berfungsi untuk mengayomi adat istiadat yang hidup ditengah-tengah masyarakat, menampung dan menyalurkan aspirasi masyarakat.

Salah satu tugas dan kewajiban BPD bagi peningkatan partisipasi adalah memaksimalkan peran dan fungsi Badan Permusyawaratan Desa,agar tidak sekedar menjadi badan formal belaka, melainkan benar-benar menjalankan fungsi untuk mengaktualisasikan kepentingan rakyat. Badan Permusyawaratan Desa harus pula mampu mewadai partisipasi politik rakyat, termasuk memperingatkan atau memberhentikan Kepala Desa jika pelaksanaan tugasnya tidak lagi konsisten dengan kepentingan rakyat.

Dalam Permendagri No.110/2016 Badan Permusyawaratan Desa mempunyai fungsi, membahas dan menyepakati Rancangan Peraturan Desa bersama Kepala Desa, menampung dan menyalurkan aspirasi masyarakat Desa, dan melakukan pengawasan kinerja Kepala Desa. Selain melaksanakan fungsi diatas, Badan Permusyawaratan Desa juga mempunyai tugas sebagai antara lain : 1) Menggali aspirasi masyarakat; 2) Menampung aspirasi masyarakat; 3) Mengelola aspirasi masyarakat; 4) Menyalurkan aspirasi masyarakat; 5) Menyelenggarakan musyawarah BPD; 6) Menyelenggarakan musyawarah Desa; 7) Membentuk panitia pemilihan Kepala Desa; 8) Menyelenggarakan musyawarah Desa khusus untuk pemilihan Kepala Desa antar waktu; 9) Membahas dan menyepakati rancangan Peraturan Desa bersama Kepala Desa; 10) Melaksanakan pengawasan terhadap kinerja Kepala Desa; 11) Melakukan evaluasi laporan keterangan penyelenggaraan Pemerintahan Desa; 12) Menciptakan hubungan kerja yang harmonis dengan Pemerintah Desa dan lembaga Desa lainnya; dan melaksanakan tugas lain yang diatur dalam ketentuan peraturan perundang-undangan.

\section{Konsep Kompetensi}

Kamus Inggris-Indonesia mengartikan competence sebagai suatu kemampuan atau kecakapan (Wojowarsito dan Poerwadaminta, 2000). Mitrani dkk (2002) yang mengatakan bahwa kompetensi adalah sifat dasar seseorang yang dengan sendirinya berkaitan dengan pelaksanaan suatu pekerjaan secara efektif dan berhasil. 
Menurut Mitrani, dkk (2002) bahwa kompetensi mengandung dua pengertian atau makna, yaitu : (1) Bidang kemampuan pengetahuan dan keterampilan yang dapat diperoleh melalui proses belajar (pendidikan, pelatihan, dan pengalaman). Kemampuan tersebut mencakup pengetahuan konseptual (seringkali kejuruan dan keahlian), dan sejumlah besar kegiatan kerja generik (seperti: menentukan sasaran, membuat rencana, memberikan penyajian/presentase), dan lain-lain. (2) Kompetensi-kompetensi yang merupakan perangai, motif atau sifat-sifat yang tertanam lebih dalam pada diri seseorang, misalnya : rasa percaya diri, daya tahan terhadap tekanan/ketegangan, keinginan untuk berprestasi, dan lain-lain. Spencer and Spencer (dalam Sudarmanto, 2009) mengatakan, kompetensi merupakan karakteristik dasar perilaku individu yang berhubungan dengan kriteria acuan efektif dan atau kinerja unggul di dalam pekerjaan atau situasi. Armstrong (2004) mengartikan kompetensi adalah apa yang orang bawa pada suatu pekerjaan dalam bentuk tipe dan tingkat-tingkat perilaku yang berbeda.

Spencer dan Spencer (dalam Wibowo, 2007) mengatakan ada lima tipe karakteritik kompetensi yaitu : 1) Motives (motif), yaitu sesuatu yang secara konsisten dipikirkan dan diinginkan seseorang yang menyebabkan tindakan. Motif menggerakkan, mendorong, mengarahkan, dan menyeleksi perilaku terhadap kegiatan atau tujuan tertentu dan menjauh dari yang lain. 2). Traits (sifat), yaitu karakteristikkarakteristik fisik dan repons-respons konsisten terhadap berbagai situasi atau informasi. 3). Self concept (konsep diri), yaitu sikap, nilai-nilai, atau citra diri seseorang. Percaya diri merupakan keyakinan orang bahwa mereka dapat efektif dalam hampir setiap situasi ialah bagian dari konsep diri orang. 4). Knowladge (pengetahuan), yaitu pengetahuan atau informasi yang dimiliki seseorang dalam bidang spesifik tertentu. 5). Skill (keahlian), yaitu kemampuan untuk mengerjakan atau melaksanakan tugas fisik tertentu atau tugas mental tertentu.

\section{Pengembangan Hipotesis dan Hipotesis Penelitian}

\section{Pengaruh Kompetensi Aparatur Desa terhadap Kualitas Laporan Keuangan}

Kompetensi adalah kemampuan atau keahlian dalam bidang tertentu yang dimiliki seseorang yang didapatkan dari pelatihan atau lembaga pendidikan formal lainnya. Keahlian atau kompetensi yang dimiliki aparatur desa akan dapat membantu aparatur desa itu sendiri dalam melaksanakan tugasnya. Semakin tinggi kompetensi yang dimiliki aparatur desa, semangkin baik pula kualitas laporan keuangan yang akan dihasilkan. Berdasarkan penjelasan diatas hipotesis dalam penelitian ini adalah :

H1 : Kompetensi aparatur desa berpengaruh terhadap kualitas laporan keuangan desa.

\section{Pengaruh Peran Serta BPD terhadap Kualitas Laporan Keuangan Desa}

Peran serta BPD dalam pengelolaan pemerintah desa, baik dari segi pemerintahan maupun pengelolaan dana desa, sangat berkaitan dengan ketercapaian atau tidaknya target dari tujuan sasaran yang akan dicapai oleh pemerintahan desa tersebut. Badan Permusyawatan Desa (BPD) adalah perwakilan dari masyarakat yang juga memiliki tugas mengawasi jalannya pemerintahan desa. Berdasarkan penjelasan diatas, hipotesis dalam penelitian ini adalah :

H2 : Peran Serta BPD berpengaruh terhadap Kualitas Laporan Keuangan Desa 


\section{Pengaruh Kompetensi Aparatur Desa dan Peran Serta BPD terhadap Kualitas Laporan Keuangan Desa}

Aparatur desa yang terdiri dari kepala desa, sekretaris desa, bendahara dan BPD hendaknya memiliki kompetensi dalam hal kepemimpinan dan pengelolaan dana desa yang telah diberikan. Jika aparatur desa memiliki kompetensi maka akan lebih mudah dalam mengatur dan mengelola dana dan desa yang dipercayakan kepadanya. Selain dari pada itu peran serta BPD dalam pemerintahan desa yang merupakan perwakilan dari masyarakat juga sangat menetukan ketercapaian tujuan untuk memajukan masyarakat serta pembangunan desa, BPD juga berperan dalam mengawasi jalannya pemeritahan dan pengelolaan dana desa serta pelaporan atau pertanggungjawaban pengelolaan dana desa ang telah diberikan, sehingga dapat mempertanggungjawabkan dan memanfaatkan dana desa untuk kepentingan dan kemajuan desa. Hipotesis dalam penelitian ini adalah :

H3 : Kompetensi aparatur desa dan peran serta BPD berpengaruh terhadap kualitas laporan keuangan desa.

\section{METODE PENELITIAN}

\section{Metode Pengumpulan Data}

Penelitian ini menggunakan metode kualitatif, penelitian kualitatif merupakan prosedur meneliti yang menghasilkan data deskriptif berupa kata-kata tertulis atau lisan dari orang-orang dan perilaku yang diamati. Metode pengumpulan data dengan cara membagikan kuesioner kepada responden sebagai instrument untuk mengukur kompetensi, peran serta dan kualitas laporan keuangan.

Data yang dihasilkan dalam penelitian ini adalah data primer, data primer adalah data yang dikumpulkan sendiri oleh peneliti langsung dari sumber pertama atau tempat objek penelitian dilakukan.

\section{Defenisi Operasional Variabel Kompetensi Aparatur Desa}

Dalam hal ini kompetensi aparatur desa didefinisikan sebagai kemampuan pengetahuan, keterampilan/kecakapan, dan sikap yang dimiliki aparatur desa di dalam menyenggarakan urusan pemerintahan di desa, yang diperoleh baik melalui pendidikan, pelatihan, maupun pengalaman. Kompetensi aparatur desa dalam penyelenggaraan pemerintahan desa dilihat dari beberapa aspek sebagai berikut :

1) Kompetensi pengetahuan/intelektual, meliputi tingkat pendidikan umum, pendidikan dan pelatihan (diklat) di bidang pemerintahan, dan pengalaman di bidang pemerintahan. Kompetensi keterampilan dan kecakapan, meliputi : Kemampuan manajerial (memimpin dan mengelola bawahan, pengambilan keputusan, kerja sama dengan badan/lembaga lain di desa), dan kemampuan di bidang manajemen pemerintahan;

2) Kompetensi sikap,meliputi : kemampuan kerja sama, disiplin, tanggung jawab, semangat kerja, dan penerapan dan pengamalan nilai etika sosial kemasyarakatan dan etika agama dan etika budaya. 
Skala pengukuran yang digunakan untuk mengukur variable kompetensi aparatur desa adalah dengan menggunakan skala ordinal.

\section{Peran Serta BPD}

Badan Permusyawaratan Desa sebagai aktor pembaruan dalam mewujudkan demokrasi di desa. Diawali dengan mengedepankan semangat Otonomi Daerah. Sebagai gantinya perlu didorong adanya legislatif partisipasi atau prakarsa masyarakat. Pengembangan partisipasi rakyat sudah barang tentu dapat dijadikan dari dua sisi sekaligus. Pertama, meningkatnya kemampuan rakyat untuk ambil bagian dari proses. Kedua, mendorong perubahan dikalangan perangkat sendiri, baik perubahan prilaku dan paradigma maupun perubahan organisasi kerja organisasi pemerintahan desa. Peran serta BPD dalam pelaksanaan roda pemerintahan desa dapat diukur dengan keikut sertaan dari BPD dalam : 1) Menggali aspirasi masyarakat, 2) Menampung aspirasi masyarakat; 3) Mengelola aspirasi masyarakat; 4) Menyalurkan aspirasi masyarakat, 5) Menyelenggarakan musyawarah BPD, 6) Menyelenggarakan musyawarah Desa, 7) Membentuk panitia pemilihan Kepala Desa, 8) Menyelenggarakan musyawarah Desa khusus untuk pemilihan Kepala Desa antar waktu, 9) Membahas dan menyepakati rancangan Peraturan Desa bersama Kepala Desa, 10) Melaksanakan pengawasan terhadap kinerja Kepala Desa, 11) Melakukan evaluasi laporan keterangan penyelenggaraan Pemerintahan Desa, 12) Menciptakan hubungan kerja yang harmonis dengan Pemerintah Desa dan lembaga Desa lainnya; dan melaksanakan tugas lain yang diatur dalam ketentuan peraturan perundang-undangan.

Skala pengukuran yang digunakan untuk mengukur variable peran serta BPD adalah dengan menggunakan skala ordinal.

\section{Kualitas Laporan Keuangan}

Laporan keuangan yang baik adalah laporan keuangan yang memenuhi unsur kekayaan dan kewajiban serta harus memenuhi standard yang berlaku dalam hal ini laporan keuangan desa harus disusun berdasarkan Standar Akuntansi Pemerintahan (SAP) yang berlaku. Menurut Sujarweni (2015), tahap dalam membuat laporan keuangan desa adalah sebagai berikut :

1) Membuat rencana berdasarkan visi misi yang dituang dalam penyusunan anggaran.

2) Anggaran yang dibuat terdiri dari akun pendapatan, belanja, dan pembiayaan. Setelah anggaran disahkan maka perlu dilaksanakan.

3) Dalam pelaksanaan anggaran timbul transaksi, transaksi tersebut harus dilakukan pencatatan lengkap berupa pembuatan buku kas umu, buku kas pembantu, buku bank, buku pajak, buku inventarisasi dengan mengumpulkan bukti-bukti transaksi..

4) Untuk memperoleh informasi posisi keuangan, kemudian berdasarkan transaksi yang terjadi dapat dihasilkan sebuah neraca, serta

5) Menghasilkan laporan realisasi anggaran desa.

6) Basis akuntansi yang digunakan dalam laporan keuangan desa adalah basis kas untuk pengakuan pendapatan, belanja, dan pembiayaan dalam laporan realisasi anggaran. Basis akrual untuk pengakuan asset, kewajiban dan ekuitas dana dalam neraca.

Laporan keuangan yang disusun oleh bendahara desa harus dicatat dan tersistem, sehingga menghasilkan laporan keuangan yang benar, lengkap, akurat, andal, dan tepat waktu. Skala pengukuran yang digunakan untuk mengukur variable kompetensi aparatur desa adalah dengan menggunakan skala ordinal. 


\section{METODOLOGI PENELITIAN}

\section{Populasi dan Sampel Penelitian}

Populasi adalah wilayah generalisasi yang terdiri atas obyek atau subyek yang kemudian ditarik kesimpulannya (Sugiyono, 2006). Populasi penelitian ini adalah seluruh aparatur desa yang terlibat dalam pengelolaan alokasi dana desa. Teknik penentuan sampel yang digunakan adalah Penarikan sample secara jatah (Quota sampling). Teknik sampling ini dilaksanakan dengan dasar jatah atau jumlah yang sudah ditetapkan. Yang dijalankan sampel penelitian biasanya adalah subjek yang mudah ditemukan sehingga dapat mempermudah proses pengummpulan data. Sampel adalah sebagian dari jumlah dan karakteristik yang dimiliki oleh populasi tersebut (Sugiyono, 2013). Sampel dalam penelitian ini sebanyak 39 orang, yang terdiri dari Kepala Desa, Sekertaris Desa, Bendahara Desa dan BPD.

\section{Metode Analisis Data}

Metode analisis data dalam penelitian ini dengan menggunakan alisis regresi linear berganda,model analisis regresi linear berganda dalam penelitian ini adalah sebagai berikut :

$Y=a+b 1 \times 1+b 2 \times 2+e$

$$
\begin{array}{cl}
\text { Dimana }: Y & : \text { Kualitas Laporan Keuangan Desa } \\
a & : \text { Konstansta } \\
\text { b1,b2 } & \text { Koefisien Regresi } \\
\text { x1 } & : \text { Kompetensi Aparatur Desa } \\
\text { x2 } & : \text { Pemahaman Akuntansi } \\
e & : \text { error term }
\end{array}
$$

\section{HASIL PENELITIAN DAN PEMBAHASAN}

\section{Uji Statistik Deskriptif}

\section{Tabel 1. Uji Statistik Deskriptif}

\begin{tabular}{lrrrrr}
\hline \multicolumn{7}{c}{ Descriptive Statistics } \\
\hline & $\mathrm{N}$ & \multicolumn{1}{c}{ Minimum } & Maximum & Mean & Std. Deviation \\
Kom & 39 & 47.00 & 65.00 & 56.5897 & 4.60959 \\
BPD & 39 & 30.00 & 50.00 & 41.6154 & 5.11250 \\
KW & 39 & 18.00 & 30.00 & 25.5385 & 2.64422 \\
Valid N (listwise) & 39 & & & & \\
\hline
\end{tabular}

Berdasarkan table 1 diatas dapat dilihat bahwa hasil dari kuesioner yang dibagikan, responden nilai rata rata yang diberikan untuk variabel kompetensi aparatur desa adalah 56,5897 dengan nilai maksimum 65,00 dan nilai minimum 47,00 . Untuk variabel Peran Serta BPD rata-rata nilai yang didapat adalah 41,6154 , dengan nilai maksimum adalah 50,00 dan nilai minimum 30. Sedangkan untuk variabel Kualitas Laporan Keuangan nilai rata-rata yang didapat adalah 25,5385 dengan nilai minimum 18,00 dan nilai maksimum 30 . 
Tabel 2 Uji Validitas dan Uji Reliabilitas

\begin{tabular}{llrrr}
\hline \multicolumn{4}{c}{ Correlations } \\
\hline \multirow{4}{*}{ Kom } & Kom & BPD & KW \\
& Pearson Correlation & 1 & $.469^{* *}$ & $.561^{* *}$ \\
& Sig. (2-tailed) & & .003 & .000 \\
& $\mathrm{~N}$ & 39 & 39 & 39 \\
& Pearson Correlation & $.469^{* *}$ & 1 & $.781^{* *}$ \\
BPD & Sig. (2-tailed) & .003 & & .000 \\
& $\mathrm{~N}$ & 39 & 39 & 39 \\
& Pearson Correlation & $.561^{* *}$ & $.781^{* *}$ & 1 \\
KW & Sig. (2-tailed) & .000 & .000 & \\
& $\mathrm{~N}$ & 39 & 39 & 39 \\
\hline \multirow{2}{*}{${ }^{* *}$. Correlation is significant at the 0.01 level (2-tailed). } \\
\hline
\end{tabular}

Hasil di atas dapat menunjukkan tingkat korelasi tinggi atau lemah hubungan setiap item. untuk mengetahui bagaimana angka hubungan tersebut, sebelumnya kita sudah tahu bahwa jumlah responden 39 , diperoleh nilai $r$ tabel $=0.2673$. nilai tersebut menjadi patokan dimana nilai hasil korelasi tidak boleh rendah dari nilai $r$ tabel tersebut. Kalau kita tinjau dari hasil semua item di atas sangat bagus sekali, dimana semua korelasinya tinggi (dapat ditandai dengan adanya tanda ** pada setiap item). seperti item $\mathrm{x} 1$ dan item $\mathrm{x} 2$ artinya semakin tinggi kompetensi yang dimiliki dan dimanfaatkan oleh aparatur desa dan semakin tinggi peran serta BPD dalam pengelolaan dan pengawasan pemerintahan desa maka akan semakin berkualitas laporan keuangan yang disajikan, serta lebih merata, hal ini dapat ditunjukan dengan nilai correlation sebesar $\left.0.781^{* \star}\right)$ dimana nilai tersebut tergolong sangat kuat dan seterusnya. sedangkan output berdiagonal 1 bisa di abaikan saja, itu bisa terjadi antar variabel yang sama atau tidak memberikan pengaruh apa-apa terhadap variabel itu sendiri, jadi tidak mempunyai analisis tertentu pada nilai tersebut.

Berdasarkan hasil uji SPSS dan Tabel diatas dapat dilihat bahwa data dalam penelitian ini berdistribusi normal, hal ini ditunjukan dengan nilai Asymp. Sig (2-tailed) yang didapat sebesar 0,594 , yang berarti lebih besar dari 0,05 .

Tabel 4. Uji Multikolinearitas

\begin{tabular}{|c|c|c|c|c|}
\hline \multirow{3}{*}{ Model } & & \multicolumn{3}{|c|}{ Coefficients ${ }^{a}$} \\
\hline & & Collinea & tistics & \\
\hline & & Tolerance & VIF & Keterangan \\
\hline 1 & $\begin{array}{l}\text { (Constant) } \\
\text { Kom } \\
\text { BPD }\end{array}$ & .685 & & $\begin{array}{l}\text { dak Multikolinearitas } \\
\text { dak Multikolinearitas }\end{array}$ \\
\hline
\end{tabular}

Sumber Data : Data Primer yang diolah 2015

Tabel diatas menunjukan bahwa data yang didapat dari penelitian ini tidak terjadi multikolinearitas yang dapat dilihat dari nilai tolerance yang dibawah 1 dan nilai VIF dibawah 10. 
Tabel 5. Uji Heteroskedastisitas

\begin{tabular}{|c|c|c|c|c|c|}
\hline \multicolumn{6}{|c|}{$\begin{array}{l}\text { Uji Glejser } \\
\text { Coefficientsa }\end{array}$} \\
\hline Model & Unstandardizec & Coefficients & Standardized & T & Sig. \\
\hline & B & Std. Error & Beta & & \\
\hline (Constant) & 100 & 3.260 & & .061 & .976 \\
\hline Kom & .285 & .144 & .264 & 1.478 & .075 \\
\hline BPD & .115 & .224 & 128 & .516 & .610 \\
\hline
\end{tabular}

a. Dependent Variable: TotalKa

Sumber Data : Data yang diolah 2015

Nilai t_tabel dalam penelitian ini adalah 1,69726. Berdasarkan uji heteroskedastisitas dengan metode Glejser diperoleh nilai t_hitung lebih kecil dari t_tabel dan nilai signifikansi lebih besar dari 0,05 , sehingga dapat disimpulkan data tidak terjadi heteroskedastisitas.

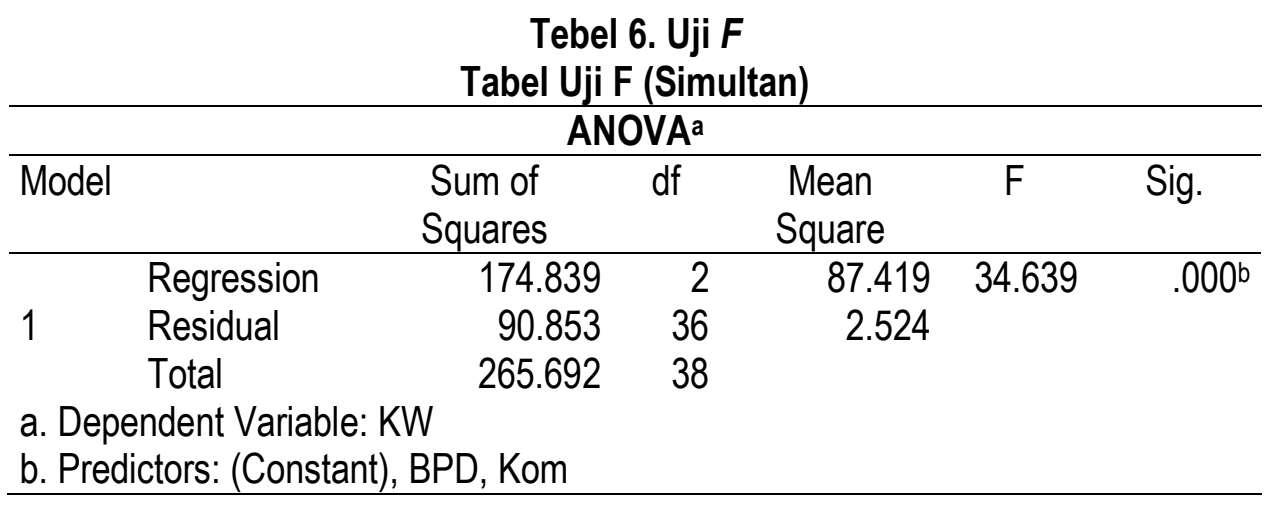

Dari tabel ANOVA diatas diperoleh nilai $F \_$hitung sebesar 34,639 dengan nilai probabilitas $($ sig $)=0,000$. Nilai $F_{-}$hitung $34,639>F_{\text {_tabel }}(2,934)$, dan nilai sig. lebih kecil dari nilai probabilitas 0,05 atau nilai $0,000<0,05$; maka HO diterima, berarti secara bersama-sama (simultan) Kompetensi aparatur desa dan peran serta aparatur desa berpengaruh signifikan terhadap Kualitas laporan keuangan desa.

Tebl 6. Uji t (Parsial)

Tabel Uji Parsial (Uji t)

Coefficients $^{\mathrm{a}}$

\begin{tabular}{|c|c|c|c|c|c|c|}
\hline \multirow[t]{2}{*}{ Model } & & \multicolumn{2}{|c|}{ Unstandardized Coefficients } & \multirow{2}{*}{$\begin{array}{l}\text { Standardized } \\
\text { Coefficients } \\
\text { Beta }\end{array}$} & \multirow[t]{2}{*}{ t } & \multirow[t]{2}{*}{ Sig. } \\
\hline & (C) & $\begin{array}{c}B \\
3.157\end{array}$ & $\begin{array}{c}\text { Std. Error } \\
3.249\end{array}$ & & & \\
\hline 1 & Kol & .143 & .063 & .249 & 2.259 & .030 \\
\hline & BPD & 343 & .057 & .664 & 6.017 & .000 \\
\hline
\end{tabular}

Dari tabel diatas dapat diketahui bahwa variabel kompetensi aparatur desa dan peran serta BPD berpengaruh secara parsial dan signifikan yang ditunjukan dari nilai t hitung yang lebih 
besar dari $t$ tabel dan nilai signifikansi lebih kecil dari 0,05. Dari hasil penelitian menjelaskan bahwa kompetensi aparatur desa dan peran serta BPD berpengaruh positif terhadap kualitas laporan keuangan, yang berarti semakin tinggi kompetensi yang dimiliki oleh aparatur desa dan semakin tinggi peran serta BPD maka akan semakin baik dan semakin berkualitas laporan keuangan yang disajikan.

Tabel 7. Uji Koefisiensi Determinasi (Adjusted R²) Tabel Hasil Uji Adjusted $\mathrm{R}^{2}$

\begin{tabular}{|c|c|c|c|c|c|}
\hline \multicolumn{6}{|c|}{ Model Summaryb } \\
\hline Model & $\mathrm{R}$ & R Square & $\begin{array}{l}\text { Adjusted R } \\
\text { Square }\end{array}$ & $\begin{array}{l}\text { Std. Error of the } \\
\text { Estimate }\end{array}$ & Durbin-Watson \\
\hline 1 & $.804^{a}$ & 647 & .610 & 1.52916 & 1.800 \\
\hline
\end{tabular}

Untuk mengukur seberapa besar hubungan antara variabel independen dengan variabel dependen adalah nilai $R$ yang ada pada tabel diatas, hasil perhitungan statistik diperoleh nilai $R$ sebesar 0,647 yang menunjukkan hubungan yang cukup mewakili antara variabel kompetensi aparatur desa dan peran serta BPD terhadap kualitas laporan keuangan.

\section{DAFTAR PUSTAKA}

Armstrong, Michael. 2004. Performance Management, terjemahan, Yogyakarta, Tugu Publesher. Bryant, Coralie dan White, Louise. 1987. Manajemen Pembangunan untuk Negara-Negara Berkembang, terjemahan, LP3ES. Jakarta

Beratha, I Nyoman. 2002, Desa, Masyarakat Desa dan Pembangunan Desa, Jakarta, Ghalia Indonesia.

Ghozali, Imam. 2013. Aplikasi Analisis Multivariate dengan Program SPSS. Edisi Ketujuh. Semarang : Badan Penerbit Universitas Diponegoro.

Mitrani, Alain. Dkk. 2002. Manajemen Sumber Daya Manusia Berdasarkan Kompetensi, Terjemahan, Jakarta. Intermedia.

Permendagri No. 113 Tahun 2014 tentang Pengelolaan Keuangan Desa

Sudarmanto, (2009). Kinerja dan Pengembangan Kompetensi SDM, Teori,Dimensi, Pengukuran, dan Impelementasi dalam Organisasi. Yogyakarta: Pustaka Pelajar.

Sugiyono. 2013. Metode Penelitian Kuantitatif Kualitatif dan R \& D. Bandung : Alfabeta.

Undang-Undang Nomor 6 Tahun 2014 tentang Desa. 